Published in Journal of Medieval and Early Modern Studies 43:3, Fall 2013, 545-71. (c) 2013 Duke University Press

\author{
Stranger Artisans and the London \\ Sanctuary of St. Martin le Grand in \\ the Reign of Henry VIII
}

Shannon McSheffrey

Concordia University

Montréal, Québec

In late 1536 and early 1537, John Curtes, leatherseller, and William Mathew, grocer, both London citizens in their mid-fifties, testified about their long memories of living in and near the precinct of St. Martin le Grand. ${ }^{1}$ St. Martin's precinct, governed from 1503 by the abbot of Westminster, was a small territory in the heart of the City of London, a minute's walk north of St. Paul's Cathedral. Westminster Abbey was, by royal grant, both a chartered sanctuary and a liberty, and its governance of St. Martin's was independent of other jurisdictions, exempt from the dictates of the City, the bishop of London, and even in some senses the king's law. ${ }^{2}$ St. Martin's privileges were, however, hotly contested by the City of London. The City especially resented the precinct's exclusion from the City guilds' control over the manufacture and retail sale of goods within the metropolitan region. The City's target was the community of immigrants, called strangers or aliens in the parlance of the day, who crowded into the precinct of St. Martin's to avoid the heavy restrictions placed on their ability to work and sell within the City's jurisdiction. The boundaries of the precinct-marked in some places by walls but at other spots by notional lines that ran down the middle of streets, houses, and churches-defined status and demarcated identities. ${ }^{3}$ The privileges were highly contested, however: from the fifteenth century into the 1530s, the City of London waged an intermittent legal and political war against St. Martin's privileges. Curtes's and Mathew's testimony was taken in the context of a particularly active phase of that conflict in the mid1530s.

In their testimony, both Curtes and Mathew spoke of having lived within the precinct of St. Martin le Grand in their younger days before moving to the neighboring City parish of St. Michael le Querne. They told a number of fascinating stories about life in St. Martin le Grand. We learn from their depositions about felons seeking sanctuary, for instance. A 


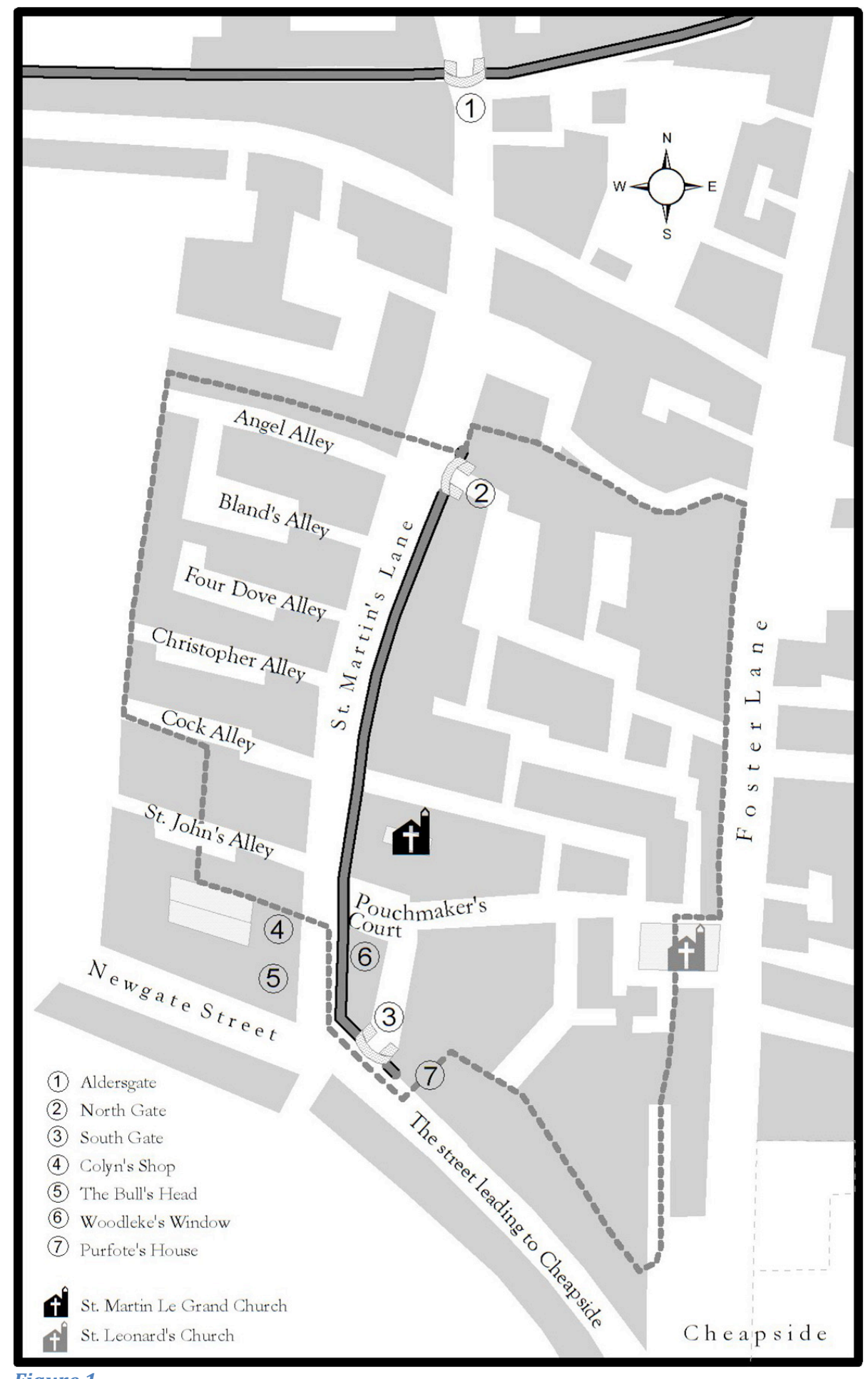

Figure 1.

Map of St. Martin le Grand (ca. 1530s)

Created for the author by Derek Parent. 
"certeyn person," one story told by Curtes goes, had lately taken sanctuary at St. Martin's after he had stolen a "sylver pece" from the Sun Tavern at Cripplegate. Once safely resident inside the precinct, the felon would frequently resort to a place called "the Seyntuary Parlour" behind the Bull's Head Tavern, on the southwest corner of St. Martin's Lane. One day, however, the officers of the sheriffs of London received information that the thief was drinking there and came and arrested him, taking him by force from the tavern to Newgate prison. Soon after, he was "put to execucion."4 Curtes also told of a shoemaker named Harry Pott, who in the reign of Henry VII was shoemaker to Prince Arthur, Henry's oldest son and heir. Either by royal "lycens" or simply by "so moche favour" from the king, Pott was able to break through a great wall on St. Martin's Lane to set up a window to display and sell his wares. ${ }^{5}$ William Mathew, for his part, related how he had become apprentice in the 1490s to Robert Purfote, a grocer who had taken sanctuary in St. Martin's as a debtor. Purfote's house and shop were situated on the east side of the South Gate leading into St. Martin's precinct. As a debtor, Purfote risked arrest if found within City boundaries. His house thus had no door into the street, the door instead opening into the entry of the gate so that Purfote could remain within sanctuary boundaries as he came and went. His shop window, however, did open up into a street in the City's jurisdiction, because he was a London citizen and could legally sell there. ${ }^{6}$ One sanctuary man named Seyntbarbe, a retainer of Lord Audley, one of the leaders of Perkin Warbeck's rebellion in 1497, had fled to St. Martin's following the defeat of the rebels. When Mathew was an apprentice, Seyntbarbe would stand in the South Gate "and talke and comen wyth suche as passed by yn the strete," and he frequently came into Purfote's shop where the teenaged apprentice became very familiar with him. ${ }^{7}$

These stories-the Sun Tavern thief being dragged from the Sanctuary Parlour; Harry Pott, shoemaker to the prince, breaking through a wall to set up a shop window into St. Martin's Lane; grocer Robert Purfote opening his door into the precinct and his window into the City street; and Seyntbarbe the fugitive traitor passing the time with people in the entry of St. Martin's South Gate-were of course not told for their own sakes, but to make legal arguments. Curtes's and Mathew's depositions were taken in the context of a specific dispute in the mid-1530s between the City of London and the abbot of Westminster over St. Martin's privileges. At its basis, the quarrel was about whether stranger artisans could ply their trades in St. Martin's Lane free from the supervision of City guilds, even though they 
were not citizens of London. The anecdotes Curtes and Mathew brought forth as evidence to address this question indicate that, for them, the question of whether stranger artisans could make and sell shoes in St. Martin's Lane was bound up in a larger complex of issues that wove together St. Martin's status as a liberty (the basis of exemption from the City's economic jurisdiction) with its claims as a sanctuary (the basis of its ability to harbor accused felons). The seizing of the Sun Tavern thief from the Sanctuary Parlour showed that the property was not sanctuary, in spite of its name, which related directly to whether George Colyn, a Dutch shoemaker, could sell shoes in a shop on the same property. Harry Pott's breaking through the wall to open up into St. Martin's Lane at the beginning of the century bore on whether Francis Woodleke, another stranger shoemaker, could do likewise thirty years later. Purfote's and Seyntbarbe's movements around the South Gate constituted evidence about precisely where the precinct's boundaries lay-and thus where the stranger artisans working in St. Martin's could work and sell-even though both were sanctuary men, not stranger artisans.

Curtes's and Mathew's depositions are typical in their conflation of sanctuary and liberty, an equiavalence not only characteristic of the testimony of about two dozen others in the dispute, but also of the submissions made both by the City and by the abbot of Westminster. ${ }^{8}$ The status of St. Martin's as a sanctuary, an asylum where accused felons could seek shelter, might seem incidental to the stranger artisans' life in St. Martin's, and conversely the dense population of alien craftsmen largely irrelevant to legal and political controversies about St. Martin's status as a sanctuary. In fact, however, the privileges each of these groups enjoyed, and saw challenged, were frequently melded together in the rhetoric that emerged from the conflict. The City of London, in its attacks on the alien workers in St. Martin's, equated them rhetorically with the "enorme enymyes of God," the unpunished and unrepentant criminals and traitors. Those defending St. Martin's argued on the other hand that the artisans of St. Martin's Lane were exempt from City craft regulation by St. Martin's "immunyteis" as "a Sentuary and a privylagid place." ${ }^{9}$ The stranger artisans not only shared physical space with the sanctuary seekers, but also stood alongside them conceptually. In the reign of Henry VIII, the control of labor and retailing came to be tightly imbricated with the larger issues surrounding crime, mercy, and due punishment that sanctuary inspired. 


\section{Peculiar London}

St. Martin's was not London's only liberty, nor its only sanctuary; indeed, medieval London was a patchwork of legal jurisdictions. A host of liberties and peculiars, small territories usually governed by religious houses, exercised varying extents of juridical and political autonomy from authorities both civic and diocesan. ${ }^{10}$ Many religious houses had tenements in their precincts, and by the fifteenth century these precincts were populated, sometimes quite densely, with inhabitants who sought for various reasons to live outside the jurisdiction of the City of London. Exempt from City and episcopal courts, many of the liberties functioned as selfgoverning enclaves. Few of these jurisdictions have left records, however, and at the same time, as they were outside the purview of the mayor and aldermen, they left relatively few marks on the London civic archives on which historians have overwhelmingly depended for their understanding of the metropolis. It is thus easy to underestimate the extent of these liberties and indeed even to overlook their existence. ${ }^{11}$ The residents of these liberties were both dependent on and deeply embedded in the official City of London, at the same time as they were apart from it, creating a double-sided existence as both excluded from the benefits of the citizenry and independent from the strictures of City authority.

St. Martin le Grand was one of the most important liberties within the bounds of the City of London and simultaneously one of the kingdom's royally chartered sanctuaries. Along with Beaulieu, Beverley, Durham, and Westminster Abbey, St. Martin's had come by the fifteenth century to exercise particularly broad privileges, as common law allowed the chartered sanctuaries to offer permanent asylum to felons seeking to escape the rigorous application of capital penalties enjoined by the king's laws. Modern scholars have focused on late medieval English sanctuaries primarily in this capacity as havens for accused lawbreakers, and thus as an aspect of the working of criminal justice. ${ }^{12}$ Particularly in the case of the sanctuary of St. Martin le Grand, however, this emphasis on felons underplays its exercise of other forms of jurisdictional immunity as a liberty, especially its exemption from the supervision and regulation of London craft guilds. By the early sixteenth century, if not before, St. Martin le Grand's "sanctuary men," the felons who were granted the privilege to live within the bounds of the precinct, were greatly outnumbered by stranger craftsmen seeking to work and sell in London outside the City guilds' restrictive regulations. 


\section{Living in the precinct of St. Martin le Grand}

St. Martin's precinct was a crowded and diverse place. In addition to the canons of the college of St. Martin's, the boy choristers (about whom we unfortunately know little), and the sanctuary men who had claimed the privilege of St. Martin's immunity, the precinct's streets, lanes, and courtyards were populated by a host of Dutch, French, and English artisans and their households.

In the late medieval and Tudor period, as in later centuries, London was England's primary destination for immigrants. Although some strangers in London were wealthy and connected international merchants from the Italian city-states, Spain, or the Hanseatic League, most were much humbler sorts, beer-brewers or artisans in the cloth and leather trades. ${ }^{13}$ Precisely when St. Martin's became a particular haven for immigrant artisans is obscured by our lack of sources for much of the medieval period. ${ }^{14}$ Some evidence indicates that significant numbers of alien shoemakers and goldsmiths were living there from at least the 1440 s, and likely earlier. ${ }^{15}$ The pace of alien settlement in St. Martin's may well have quickened in the later fifteenth and early sixteenth century with the general increase in migration from the Continent and the development of more effective City supervision over alien workers. ${ }^{16}$ Certainly by Henry VIII's reign-the point at which records allow us to trace more precisely the individual inhabitants-stranger artisans demonstrably made up a significant majority of the precinct population.

Using the evidence of tax records, rent rolls, wills, denization patents, and the records of royal courts, among other materials, it is possible to build a picture of who lived in St. Martin's in the first half of the sixteenth century. Working with these sources, I have been able to identify more than five hundred residents of the precinct of St. Martin le Grand, some of them appearing in many different records. ${ }^{17}$ Precise statistics are not derivable from these sources because of their patchy nature and vagueness, the mutability of names, and the impossibility of knowing how representative the surviving records are. One particular record, the 1541 subsidy assessment, likely constitutes the most accurate snapshot we have of the makeup of the precinct's population. ${ }^{18}$ The subsidy labeled those born outside the realm as "alyen" or as "denizen," the latter term designating a stranger who had been granted, by the king's patent of denization, some, but not all, the privileges of those born in the realm. Denizens remained at a considerable disadvantage in comparison to the native-born, especially in the City of London where only citizens could sell at retail; denizens were also taxed at the same 
rate as aliens. ${ }^{19}$ The raw data from the 1541 assessment roll is striking: 207 aliens and denizens and only 5 English taxpayers are listed for St. Martin's precinct. Even making adjustments to the data, since the raw data significantly undercount the English, the numbers still suggest an overwhelming majority of the precinct population consisted of strangers: about 82 percent stranger and 18 percent English. ${ }^{20}$ This is borne out in general in all the other sixteenth-century records, which suggest that somewhere between eight and nine of every ten inhabitants of the precinct were born overseas.

Despite the significant amount of surviving evidence about those who lived in St. Martin's, when imagining life in the precinct we are nonetheless handicapped by the biases of the sources. We can only guess, for instance, about the number of women who lived there, as most of the sources record women only exceptionally, and they are clearly underrepresented in the data. The subsidy assessment rolls name all alien men over fourteen, including male servants and sons, but not wives, daughters, or female servants. Women were recorded only if they were heads of households, evidently not a common circumstance in St. Martin's (the 1541 subsidy, for instance, records only four women heading households in the precinct). ${ }^{21}$ Wives were named only spottily in a few other kinds of sources, such as wills and denization records.

The sources may also considerably skew the sex ratio in the precinct. Some of the male servants named in the subsidies (sometimes bearing generic surnames such as Henry Ducheman and Deryk Ducheman) were likely in London transiently, working abroad for a few years before returning overseas to marry and establish a shop at home. A significant proportion of the alien population, however, especially the householders, were permanent migrants, and probably most of them married and had daughters living with them as well as sons. In many of the cases where alien men's wives are known, those wives were also strangers or likely to have been so judging by their forenames. They married either before coming to London or through the social networks of immigrants they lived and worked among in the metropolis. Arnold Marsellus, Dutch shoemaker, for instance, was married to Elizabeth Tijsman, the sister of Gabriel Tijsman, another Dutch shoemaker living in St. Martin's. ${ }^{22}$ In other cases, alien men married English women, as did Gabriel Tijsman himself; his widow, Emma, was assessed as one of the wealthiest inhabitants of St. Martin's precinct soon after his death in 1541, and she was categorized as English. ${ }^{23}$

Most strangers in St. Martin's were "Doche," in the larger fifteenthand sixteenth-century sense of that word, which stretched to include 
migrants from the Rhineland areas around Cologne as well as Flanders and the Low Countries. Those who through wills or other sources can be traced more precisely were from Brabant, Holland, and Cologne. ${ }^{24}$ Although much smaller in number, there was also a significant minority in St. Martin's born in France. ${ }^{25}$ For those who settled in London permanently, we know little about why they chose to move there. The most commonly cited motivation for emigration from the Netherlands in the second half of the sixteenth century-religious strife-was not yet a factor, although fifteenth-century political unrest and warfare may have played a part.26 The chain migration patterns of Dutch immigrants to England in the fifteenth and first half of the sixteenth century suggest that already-existing family and occupational networks tied to the old country were a significant factor in settlement choices. ${ }^{27}$ The two dozen wills I have been able to find of those who lived in the precinct show ties of family and friendship among the migrants, as well as maintenance in some cases of property and family ties in the old country. We know that some immigrated as children, probably although not certainly with their parents. The stranger householders often employed a number of their countrymen as servants-indeed, this was a sore point with local journeymen and apprentices. ${ }^{28}$

Dutch and French immigrants came to St. Martin's because it was a stranger enclave, but most of all they congregated there because they could practice their trades in the precinct, outside the reach of the London guilds. Perhaps (as their English counterparts claimed) their exemptions from the London guilds gave them a competitive advantage, and certainly prosperity greeted some who settled in the precinct, as the tax assessment rolls indicate. The most common occupations of strangers in St. Martin's were cordwainer (shoemaker), pouchmaker, and leather-dyer or leather-seller, with a small but significant number of goldsmiths. It is not clear whether St. Martin's was a magnet for immigrants involved in the leather trades, or whether immigrants coming to St. Martin's shaped their occupational choices according to the dominance of shoemaking and other leather work there. Probably both factors came into play.

While for most craftsmen in sixteenth-century London guild membership was central to forming occupational identity and solidarity, the Dutch artisans in St. Martin's were generally not guild members. They thus did not wear guild livery or observe collective ceremonies or festivals; nor were training and apprenticeship supervised by guild masters and wardens, except of course any training they may have had in their cities of origin before migration. The lack of formal guild structures, however, 


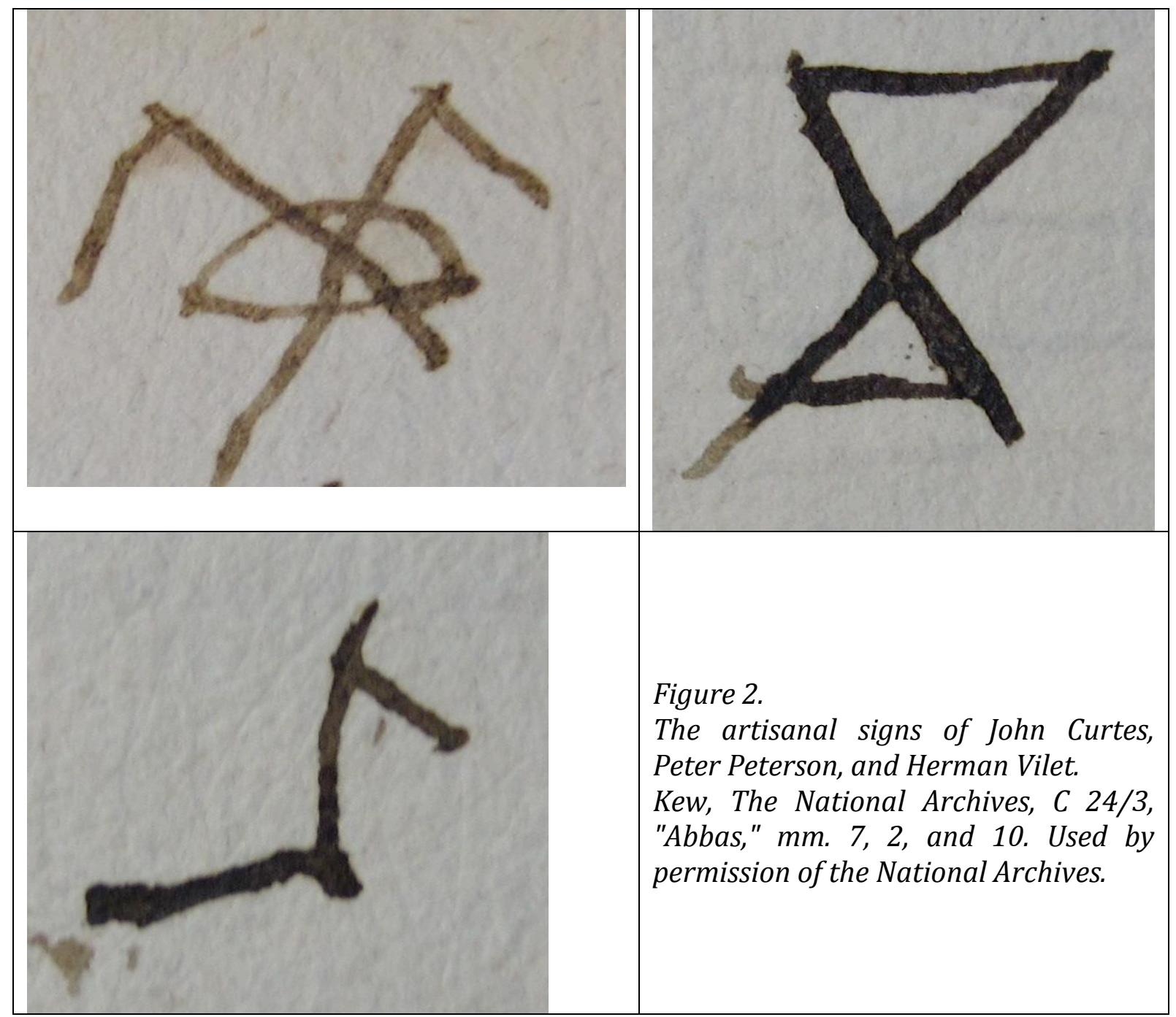

did not necessarily mean the lack of a strong individual and collective occupational identity among the various artisan groups working in St. Martin's precinct. Many of the witnesses, for instance, both English and alien, who testified in 1536 regarding the boundaries of St. Martin's precinct signed their depositions with their artisans' marks, indicating a common vocabulary of acknowledging individual craftsmanship, shared between native and immigrant. ${ }^{29}$ Figure 2, for example, shows the English artisans' marks of the citizen leatherseller John Curtes, the denizen shoemaker Peter Peterson, and the denizen barber Herman Vilet.

If the craftsmen in St. Martin's had commonalities with English artisans, they may well also have set themselves apart from their London peers. The craftsmen of St. Martin's had reason to take pride in their workmanship, and indeed perhaps to regard their expertise as superior to English skills. Although London guildsmen often loudly complained about shoddy workmanship among those outside guild supervision, this was likely mere 
bluster, as goods produced by strangers were evidently popular with consumers and regarded as having a certain cachet. ${ }^{30}$ For more than a century, St. Martin's precinct was evidently the place to buy stylish shoes, for instance. In the 1460s, St. Martin's shoemakers were exempted from a statutory ban on shoes with fashionably long points, and in the 1570s a London shopping guide indicated that St. Martin's Lane was still the best place to buy footwear. ${ }^{31}$ In a similar way, some Dutch goldsmiths working in St. Martin's Lane were much sought after, as were other gold workers from the Netherlands working in other liberties in the capital, their skills generally acknowledged to be superior to English work. ${ }^{32}$ Although evidently restrictions on their capacity to make and sell their goods affected aliens' work lives, the privileged environment of St. Martin's and the relative independence and freedom it conferred were probably more than sufficient compensation.

\section{Governance in the precinct}

Prior to the dissolution of the monasteries, the inhabitants of St. Martin's, living in its peculiar jurisdiction, were subject neither to the bishop of London's ecclesiastical courts nor the City's ward mote inquests or other courts. There are some traces of the precinct's spiritual and temporal courts, which dealt with disputes among and discipline over those who lived within its bounds. ${ }^{33}$ Unfortunately, however, we know little about these aspects of St. Martin's, as few administrative records of the precinct survive.

We do know something about the constable of St. Martin's, a lay official who represented the abbot and held a considerable measure of power in the precinct. For much of the first half of the sixteenth century, from at least 1503 until 1543, one man, Hugh Payne, held the position of constable, and later added the office of rent-gatherer. ${ }^{34}$ Payne was originally a citizen leatherseller of London; along with many other men in early Tudor England, he seems to have regarded offices in the service of a great landlord to be the path to greater prosperity. As constable, his duties were broad, seemingly touching on every aspect of the precinct's operations. It was he who formally registered the felons and debtors who sought the privileges of St. Martin's, likely keeping a register (which, unfortunately, does not survive). ${ }^{35}$ As the primary law enforcement officer of St. Martin's, he operated the prison within the precinct. Those who sought sanctuary for felony would be incarcerated there until they had been admitted to the privilege, and those who were accused of misbehavior of various kinds would be confined there awaiting process before the precinct's steward. ${ }^{36}$ Payne's duties extended also 
to administration of the ecclesiastical side of the precinct. In 1542, as part of the dissolution process, he submitted an account for payments he had made throughout the year. ${ }^{37} \mathrm{He}$ oversaw a broad swathe of administrative tasks, paying out salaries to the collegiate church's clergy, clothing the choristers, purchasing the necessaries for the church ("syngyng brede," lamp oil, incense, and the like), administering repairs, and generally maintaining the precinct, including payments to the "gonge farmer" to haul away sixteen tons of waste over the year.

Payne also came over the decades to control much of the property in St. Martin's precinct, apparently using his position as rent-gatherer to snap up leases on properties held by Westminster Abbey when they became vacant. The abbot's lease book shows him gradually amassing more and more leases, and many of the Dutch and French artisans who had shops in the precinct sublet their properties from him. ${ }^{38} \mathrm{He}$ also took up leases on some of the abbey's manors in Essex, and a lawsuit in Common Pleas and King's Bench in the mid-1510s shows him trying to acquire other agricultural property in Essex as well. Over the decades, he served as constable, and he sought to make a transition from pouchmaker or leatherseller to man of property. Already in a suit in Common Pleas in the mid-1510s, he was styled (or more likely styled himself) "Gentylman" on the document recording the land sale, although in this suit he was otherwise called "powchmaker." He lived in a large tenement on the north end of the precinct with a garden and stable. When he died in 1543, he left more than thirty tenements and shops to his widow. ${ }^{39}$

As both constable and major leaseholder, Payne had considerable power in the precinct. In a Chancery bill submitted between 1529 and 1532, the plaintiff, Henry Garratson, contended that Payne used his position as constable to put pressure on those who sublet property from him. Payne and Garratson quarreled over the latter's lease of a victualling house in the precinct, a quarrel that became so heated that, Garratson claimed, Payne plotted to have him murdered. Using his position as constable, Payne arrested Garratson on a trumped-up charge, treating him very roughly as he took him into custody, casting him "flatt upon the erthe" and beating him. Garratson claimed that "Hughe Payn usyth and behavyth hym sylffe as a person nott feryng the kynge nor hys lawys," who avenged himself on the inhabitants of St. Martin's "whiche wyll not be obedyent unto hym after hys wyll and plesur." 40 Other complaints similar to Garratson's were made by other Dutch artisans in the 1530s. If more extreme aspects of these grievances-Garratson's fear, for instance, that any moment Payne might 
have him murdered-do not ring true, the patterns of Payne's land acquisitions and the complaints about his exercise of office in the precinct suggest that Payne had become something of a "Tyraunt," as one complaint put it. ${ }^{41}$ Payne's career demonstrates that the self-governing nature of St. Martin's as a peculiar enclave could give rise to manipulation and appropriation of legal authority by a single individual.

\section{Strangers in the realm and the city}

As strangers, the Dutch and French artisans who lived in St. Martin le Grand were marked literally as "alien," as other. During the 1530s in particular, we are able to learn a good deal about the precinct precisely because the working lives of those stranger artisans came under concerted attack from the City of London and its guilds, an attack that left lawsuits, Crown commissions, and detailed depositions in its wake. These records suggest that the lives of the humble economic migrants who settled in St. Martin le Grand were caught up in many of the major issues of the 1530s, from the domestic and international repercussions of the Reformation to trade and labor disputes, particularly with the City of London.

The 1530s were a difficult decade for strangers in England, particularly the Dutch and French. Foreigners, especially the Dutch, were strongly associated in the 1530s with Anabaptism and radical challenges to established authority. ${ }^{42}$ The international political situation was closely tied, from the 1530s onward, to religious differences, which in turn created questions of loyalty among those born outside the king's obeisance. Beyond their presumed association with the radical dissenters coming from the Continent, as the 1530s moved into the 1540s the stranger artisans living in St. Martin's were also increasingly objects of suspicion as subjects of the Holy Roman Emperor and the king of France. In 1540, aliens resident in England were required to swear an oath of loyalty to the king and to take out patents of denization, or quit the realm..$^{43}$ In this climate, the exceptions hitherto made for St. Martin's residents, usually exempted from restrictions on strangers, no longer pertained. The publication of the 1540 act prompted the French ambassador to appear at the royal court to ask the king's advisors whether "the straungers who dwell in the Sentuaryes as at St Martins and others" were to be treated as exceptions to the act, as they always had been before, or whether they, too, must become denizens or quit the realm. The answer was curt: "They must obey the tenour of th'acte."44 The implication of the French ambassador's question is that this was a new situation, that hitherto 
St. Martin's and other liberties had remained places apart from the normal processes regarding strangers. The 1540 act obligated the strangers living in liberties at least to become denizens. Many residents of St. Martin's had already done so, but in the months following, at least fifteen long-time residents of St. Martin's, who had apparently not previously found it worth their while to pay for a patent of denization, did so. ${ }^{45}$

If the general situation for aliens in England was somewhat more hostile than it had been, the 1530s was also a decade when the longstanding dispute between the City of London and stranger artisans working and selling in St. Martin le Grand entered an intensely active stage. The City of London had made considerable strides in the later fifteenth and early sixteenth century in its ability to supervise and control immigrant labor in the metropolitan region. Through statutes from the 1480s into the 1530s, the City gained greater jurisdiction over anyone working in craft production within a two-mile radius of the City, particularly aliens. St. Martin's remained a stubborn exception, however, time and again being exempted by the Crown from the restrictions on alien labor and selling at retail. ${ }^{46}$ If the City was disappointed anew in 1529 when a labor statute once again explicitly exempted St. Martin's, it may have been mollified by the striking of a Crown commission to investigate the privileges of St. Martin's. ${ }^{47}$ That commission, which in due course received submissions from the City and the abbot of Westminster, appears not to have resulted in any change of policy regarding St. Martin's privileges, however. ${ }^{48}$

Unquestionably the special status of St. Martin's, continually upheld by the crown, rankled with the City and its guilds. Frustrated, they began to challenge St. Martin's privileges in forceful terms. At some point in the early 1530s, for instance, four Dutch shoemakers in St. Martin's lane, Arnold Marsellus, Ralph Twynge, Cornelius Hoberd, and Harry Garretson, complained that unnamed "peple" (likely the Cordwainers' Guild, although here characterized as unknown and unlawful rioters), discontented with the exemption of St. Martin's in the recent alien labour statutes of 1523 and 1529, had "commyttid dyvers Ryottis" in the precinct, breaking into their shops and seizing their wares. ${ }^{49}$

The conflict that generated the most records-as it occasioned another Crown commission to inquire more largely into the privileges of St. Martin's precinct-stemmed from another seizure of shoes and boots. This clash began in late 1533 when the City chamberlain raided two shoe shops in St. Martin's Lane belonging to stranger shoemakers Francis Woodleke and George Colyn. The raid took place soon after both Woodleke and Colyn 
seem to have decided literally to push the boundaries of the precinct of St. Martin le Grand. Woodleke broke through a wall that ran up the east side of St. Martin's Lane in order to make a shop window to sell out into the street. Although according to a number of the later inquiry's witnesses there was good precedent for his window, others argued that goods sold through this window were clearly being sold into the City, which was forbidden to Woodleke as a stranger. Colyn, for his part, set up a shop on the other side of the street in a tenement known as the Sanctuary Parlour, which had formerly been an extra drinking room attached to the Bull's Head Tavern. The Bull's Head was, all agreed, outside the sanctuary boundary, but the status of the Sanctuary Parlour was less clear. As we saw with John Curtes's testimony outlined earlier, some claimed that sanctuary men had been able in the past to drink there. Most witnesses in the later inquiry, however, were inclined to think that it was not, in fact, part of the sanctuary.50 On December 18, 1533, the chamberlain, George Medley, accompanied by thirteen or fourteen other people, came into Woodleke's and Colyn's shops and seized their stock, some thirty-nine pairs of shoes and twenty pairs of boots, taking them away in sacks, bags, and baskets to the Guildhall. ${ }^{51}$ Over the months that followed the raid on Woodleke's and Colyn's shops, the Dutch shoemakers and the City made complaint and counter-complaint both directly to Thomas Cromwell, by then the king's right-hand man, and in the royal law courts regarding "the matter of Seynt Martyn." 52 The matter dragged on for about eighteen months, until the king commissioned an inquiry to examine both the boundaries and the privileges of St. Martin's precinct. ${ }^{33}$

In the rhetoric produced by both sides in this legal conflict, St. Martin's different privileges, for felons and debtors on the one hand and stranger artisans on the other, were, time and time again, conflated. ${ }^{44}$ For those arguing for St. Martin's privileges, the right of the shoemakers to sell in St. Martin's Lane was anchored in St. Martin's ecclesiastical immunities, in its status as a sanctuary. ${ }^{55}$ For the City's argument against St. Martin's, the "pretensed" sanctuary and its sheltering of heinous criminals had never existed legitimately, and thus the stranger shoemakers could not work and sell there. The City's case could be proved by a series of precedents that mixed cases showing the legitimate arrest of felons in the precinct with others showing the subjection of the "open Schoppis" in the precinct to the jurisdiction of the City's guilds. ${ }^{56}$ Even the king's commission of an inquiry in 1535 to determine the boundaries of the sanctuary asked the commissioners "diligently [to] vieu and trye owt all and every the boundes and lymytes of the said Sanctuarye," and to examine "the grauntes, licences and confirmacions" 
made to the abbott and his predecessors concerning it. Why did the king order this inquiry? "As we be credible enfourmede," an alien shoemaker was selling shoes at retail in the lane. A clear report of the usage of the sanctuary was needed in order to determine whether his shoe shop was legal. ${ }^{57}$

The signals sent by the terms of the inquiry in 1535 suggested that the winds were blowing against the stranger shoemakers. Sanctuary, a privilege tied specifically to religious houses, was clearly in jeopardy in the mid-1530s as the monastic dissolutions began; if St. Martin's liberties were tied to its sanctuary privileges, neither seemed likely to survive. But the immediate outcome of the 1535-37 commission was maintenance of the status quo. Although once more no decision or outcome of this inquiry made by the king's council survives, we can infer that the decision sided with the abbot of Westminster and St. Martin's, or that no decision was made, which had the same effect. ${ }^{58}$ For the moment, as of 1537, both the sanctuary and the liberties of St. Martin's remained. As we will see, the sanctuary was not to last long-it was dismantled at St. Martin le Grand by a statute of 1540but the liberties survived, the braiding together of sanctuary and liberty in the rhetoric of the 1530s separating once again..$^{59}$ George Colyn's shop in the Sanctuary Parlour was probably closed, but he may simply have moved up the street, as he was living and working as a shoemaker in the precinct of St. Martin le Grand, in St. Martin's Lane, as late as 1545. Francis Woodleke continued to occupy his shop, with the window opening out into St. Martin's Lane, into the 1540 s. ${ }^{60}$

\section{Stranger artisans and sanctuary seekers in St. Martin le Grand: Complexities of identity}

Despite the Crown's rhetoric about dangerous strangers, and the struggles between alien craftsmen and the City, we cannot assume for the Dutch and French who lived in St. Martin's that the lines of conflict always ran along the most obvious categories of identity, English versus alien. Indeed those identities in themselves-English and alien-were thorny for many who lived in St. Martin's. Among the aliens, social negotiations with their neighbors, fellow strangers, and the English could be complex.

If a number of cases heard in the royal courts in Henry VIII's reign emphasized English hostility toward strangers in St. Martin's, those courts also heard cases where aliens alleged victimization by their own countrymen. Those who were immigrants themselves were well placed to take advantage 
of the vulnerable newcomer. In the mid-1540s, for instance, a shoemaker named John Albertson, alias John a Cullyn (that is, from Cologne), told a long and complicated story about a scam perpetrated on him in the late $1520 \mathrm{~s}$ and 1530s when he first arrived in the precinct as an immigrant from Cologne. ${ }^{61}$ Although it is not clear whether the main culprit, Lionel Arundell, was English or alien, at least three others whom Albertson names as having been involved in this swindle were fellow Dutchmen: Harry Pott, Harry Wesell, and Peter Peterson. ${ }^{62}$ By the 1520s Pott and Peterson had long been resident in the precinct, Peterson from childhood. Immigrants who arrived as adults, who likely strongly signalled their stranger identities both linguistically and culturally, differed from those who had come to England as children, who might have had aspirations to assimilate to the host culture. If John Albertson fit into the first category, the adult newcomer, one of his alleged harassers, Peter Peterson, fit into the second, the migrant child assimilated to English ways. Peterson indeed became so well integrated into the host culture that he became an officer of the London Cordwainers' Guild and a leading figure in the company's campaign against the Dutch shoemakers' shops in St. Martin's Lane. Yet his identity remained complicated.

Peterson was born in the province of Holland about 1481 and first came to live in St. Martin's in the early 1490s when he was eleven. He first appears in extant records in 1514, at about age thirty-three, when he acquired the lease on the property called the Greyhound on the west side of St. Martin's Lane. From that date he pops up in various records participating in St. Martin's affairs. In 1527, by then in his mid-forties, he became a denizen, and some time between then and the mid-1530s he was granted London citizenship, an unusual transition for a stranger shoemaker. ${ }^{63} \mathrm{He}$ presumably gained the freedom through the Cordwainers' Guild, of which he became a member and later warden. ${ }^{64}$

In the great quarrel between the City and the Dutch shoemakers in St. Martin's precinct, Peterson sided decisively with the City and the Cordwainers' Guild, as he was one of those acting for the City in the raid on Woodleke's and Colyn's shops in $1533 .^{65}$ He may already at that point have been warden of the Cordwainers' Guild and quite possibly was the origin of the complaint leading to the raid. His actions appear unfriendly, to say the least. Both Woodleke and Colyn were not only fellow Dutch shoemakers, but also close neighbors: Colyn's shop in the Sanctuary Parlour was located next door to Peterson's shop in the Greyhound, and Woodleke's new window was directly across the lane.

But Peterson may not, in fact, have seen himself as a fellow Dutch 
shoemaker or as a stranger per se. Despite being born outside the realm, he had lived in England from childhood and probably spoke English without accent. The cordwainers would no doubt have welcomed a friendly shoemaker living in St. Martin's Lane who was willing to undertake the responsibilities of guild membership and presumably to follow the guild's and City's regulations regarding production and sale; this allowed them more easily to make the argument by precedent that St. Martin's was, in fact, part of the City, and its shoemakers subject to their supervision. Nonetheless, Peterson's citizenship, and the privileges it bestowed, may have been somewhat ambiguous. His record on the 1541 subsidy roll illustrates his liminal status: he was listed among the "Englyshemen," as distinct from the "Alyens," but was labelled as "denyzen" and assessed as an alien rather than an Englishman (aliens paid double the rate). ${ }^{66}$

For Peterson participation in the raid was both a way to declare clearly his loyalties to his craft guild and to eliminate, rather conveniently, two rivals to his shoe shop. The latter goal was not achieved, as both Woodleke and Colyn continued to live and work in St. Martin's Lane as shoemakers. Peterson was, however, much more successful than his rivals in the years following the raid; his assessment in 1534 was in the same range as Woodleke's and Colyn's, but by 1541 his assessment marked him as the wealthiest person in the precinct by a significant margin. ${ }^{67}$

Yet Peterson had not rejected his Dutch roots entirely. Like his neighbors, he gave testimony in 1536 about his understanding of the boundaries of St. Martin's precinct, and his testimony did not entirely follow the City's line. ${ }^{68} \mathrm{He}$ did not mention that he had been involved in the raid on Colyn's and Woodleke's shoe shop, although unsurprisingly he testified, in forceful terms, that Colyn's shoe shop in the Sanctuary Parlour was inside City jurisdiction. He also declared that although the street outside Woodleke's new window was indeed sanctuary, nonetheless the window contravened an agreement that the City and the dean of St. Martin's had made long before, that no shops would open into the street from that wall. Otherwise he agreed that the shops along St. Martin's Lane were within the liberty of the sanctuary, thus implicitly contradicting the City's case that the precinct as a whole was fully subject to the City and its guilds' supervision. ${ }^{69}$

Peterson continued to live in St. Martin's Lane for the rest of his life. As a citizen cordwainer, he could have lived anywhere in the City, and yet he stayed there. His widow, too, continued to live in St. Martin's precinct after his death. Peterson was presumably not on good terms with Colyn, Woodleke, and Albertson - all of whom remained resident in St. Martin's. ${ }^{70}$ 
Peterson and his wife, however, did have strong social ties with other Dutch shoemakers in the precinct through the $1540 \mathrm{~s} .{ }^{71}$ Like many immigrants, Peterson lived in both worlds.

Peterson was more assimilated into English culture than most who lived in St. Martin's, but for many who lived there this was a difference of degree rather than kind. Many of the long-time residents in St. Martin's were integrated into the society they inhabited. If born outside the king's obeisance, the strangers were nonetheless keen to use his law and his courts, both to complain against rough or unfair treatment by London citizens and to mediate disputes amongst themselves. The inhabitants of the precinct also participated in administering the king's justice. We see local men acting as jurors in coroner's inquests, reporting the circumstances in which an unnatural death had occurred within the precinct. In six such inquests for homicides within the precinct found among the indictments filed at King's Bench, the juries were dominated by men with Dutch names, undoubtedly reflecting the precinct's makeup. ${ }^{72}$ This was true both for homicides involving Dutchmen and in cases where those involved were likely or certainly English. ${ }^{73}$ As did men in other neighborhoods in the city and throughout the realm, the substantial householders in St. Martin's served the king as jurors and probably in other capacities as well.

St. Martin's also played host to "sanctuary men," a term that encompassed felons, trespassers, and debtors. It is hard to know how many sanctuary seekers would have lived in St. Martin's at any one time, as their sojourn there was often temporary (debtors might clear their debts, and accused felons or trespassers would often use time in sanctuary to arrange a pardon). The one extant census of sanctuary seekers in St. Martin's-a short report dated 1525 now in the State Papers-may be representative, listing eleven men and one woman. ${ }^{74}$ Three on this list are identified as being in sanctuary for murder, two for unspecified felony, one for trespass, and one for debt; the other five have only their names listed. The indictments deposited in the court of King's Bench from the early fifteenth century through the first half of the sixteenth century similarly indicate regular, but not particularly frequent, recourse to St. Martin's by felons. ${ }^{75}$ Felons in the London area were much more likely to take sanctuary in the precinct of Westminster Abbey (one 1533 census of sanctuary seekers there, for instance, records ninety-two people), but conversely the abbey's precinct did not host a large number of strangers. ${ }^{76}$

Although most sanctuary seekers do not seem to have settled permanently in the precinct, in some cases they became fixtures. When witnesses 
testified in the 1530s regarding how sanctuary men observed the boundaries of the sanctuary when they walked up and down St. Martin's Lane, they referred specifically to two well-known sanctuary men, both traitors who took part in Perkin Warbeck's rebellion in 1497. Seyntbarbe, whom William Mathew as an apprentice saw visiting Purfote's grocery shop, lived in St. Martin's for twenty years. ${ }^{77}$ Other sanctuary men integrated into the precinct by becoming assistants (perhaps henchmen) to the constables; Harry Garretson said that when Hugh Payne roughed him up he was assisted by Henry Coly, sanctuary man. ${ }^{78}$ The abbot leased a chamber in the late 1530s to William Selby, another "seyntory man," who from other records appears to have been a debtor. By the 1540s, Selby had become an assistant to Payne's successor as constable in the precinct, and he was also accused of violence and intimidation against residents. ${ }^{79}$

When the stranger artisans of St. Martin's testified about the precinct's boundaries in the mid-1530s, and thus about their right to work and sell within its limits, they referred often to the habits of the sanctuary men - where they lived, where they walked, where they stood. ${ }^{80}$ Although the stranger artisans could not work in their crafts or sell their goods within City jurisdiction, nothing barred them from walking the streets of London. For those who sought the privilege of sanctuary, however, remaining within the boundaries of the precinct was literally vital, as one step out of bounds made them liable to arrest and, for the felons whose admission to sanctuary was an admission of guilt, execution. For the stranger artisans and their English neighbors who testified about where those sanctuary men lived, walked, and stood, the routes those notorious felons and traitors walked were emblematic not only of the asylum the sanctuary offered the felons but also of the privileges the precinct offered to the stranger artisans. In the rhetoric emerging from the conflict between St. Martin's and the City of London in the 1530s, the stranger artisan and the sanctuary man frequently shared a conceptual as well as a physical space.

Of course it was not impossible for aliens to be accused felons, and there is one example of just such a person in St. Martin's: John Richardson, shoemaker and alien of Southwark and St. Martin le Grand, was pardoned for murder in 1521, for having killed "Berne Ducheman alias Barnard Shomaker" of Southwark, presumably one of his compatriots as well as a fellow shoemaker. An alien shoemaker named John Richardson, almost certainly the same man, remained a long-time resident of the precinct even after he received his pardon and indeed appears to have been living there from long before the homicide. ${ }^{81}$ Richardson's example exhibits multiple tendencies 
among St. Martin's residents: as a felonious sanctuary seeker, his stay was temporary because he received a pardon; as a stranger craftsman, he continued to live in St. Martin's because he needed the precinct's liberties to practice his trade.

\section{The Dissolution and beyond}

In 1563, Garret Williamson, a Dutch shoemaker of St. Martin le Grand, made his will. He had lived in St. Martin's Lane from at least 1526, when he first rented a tenement there from the abbot. His tax assessments from the $1530 \mathrm{~s}$ and 1540s show considerable, but not extraordinary, prosperity. ${ }^{82} \mathrm{He}$ evidently maintained ties with the old country even four decades after migrating to London; in his will, he mentioned land he had bought near Antwerp and that he had left "a writinge" in the custody of a bookbinder in that city outlining debts owed to him, suggesting time spent there recently. Some of his family remained in the Low Countries-bequests were made to his brothers' and sisters' children "overseas" - but some had evidently also come to London, as his brother was described as living in Southwark. Several familiar St. Martin's names appear in the will. John Cullin-possibly the same John a Cullyn, alias John Albertson, who had been swindled when he first arrived in St. Martin's in the late 1520s, around the same time as Williamson himself first leased property in the precinct-is named as his brother, possibly what we would term brother-in-law. A Peter Peterson is also named, probably the nephew and namesake of the man whose life story was told above. ${ }^{83}$ Williamson wanted to be remembered fondly by those who lived in the precinct, leaving to his "frendis and neighboures" fifteen shillings for "a Recreacion." Most of his estate, other bequests all being paid, was to go to his "welbeloved wife" Joan and his daughter Mary. While many of his ties suggest embeddedness in the Dutch community in St. Martin le Grand, the title Williamson gave himself in his will, "Yeoman," seems very English.

Over the nearly four decades Williamson lived in St. Martin's, from the 1520 s through the 1560 s, he saw many changes to the precinct. The most obvious were those associated with the Reformation. If in the $1520 \mathrm{~s}$ and 1530s sanctuary men were to be seen strolling through the streets of St. Martin le Grand-indeed defining the precinct's boundaries by the routes they took-they were no longer walking there after 1540. In that year, Parliament passed an act changing the basis of sanctuary, stripping the privilege from St. Martin's and most of the other chartered sanctuaries. ${ }^{84}$ The collegiate 
church of St. Martin's, with its canons and choristers, was dissolved two years later, in 1542. The imposing church of St. Martin le Grand, which had dominated the precinct, was razed in the late 1540s, the site subsequently occupied by the same kinds of tenements that lined St. Martin's Lane and the other alleys and courts. The destruction of the great church significantly affected the view out Williamson's front door, living as he did across St. Martin's Lane from the site. It is more difficult to know how the Reformation affected Williamson's interior religious life. The preamble to his testament is conventionally reformed, as would be expected for a will made in 1563, the language standard and formulaic enough to give no certain sign of his personal beliefs. Unlike some who lived in St. Martin's, he did not become a member of the Dutch church, remaining a parishioner of the church of St. Leonard Foster Lane, his will witnessed by the rector of the parish.

The Reformation wrought significant changes in St. Martin le Grand, yet in many ways, Garrett Williamson's life in St. Martin's likely did not significantly change when the sanctuary and the collegiate church to which it had been attached were dissolved. Williamson continued to live in St. Martin's Lane and to work there as an alien shoemaker. The dissolution did not affect the precinct's liberties, as distinct from its sanctuary privileges and ecclesiastical immunities. The king granted the liberties to the newly created dean and chapter of the cathedral of Westminster, heir to the Abbey, and the precinct continued to function in the same way it had since the late Middle Ages. ${ }^{85}$ The rentals and tax records before and after 1542 indicate that the same people remained resident in the same properties, taking advantage of the same exemptions from City jurisdiction. St. Martin's remained jurisdictionally independent from the City for centuries more, until the early nineteenth century when the precinct was leveled to build the new General Post Office. ${ }^{86}$ From the point of view of the City of London, St. Martin's irritating jurisdictional immunity from guild supervision endured. Garret Williamson, George Colyn, Francis Woodleke, and their fellow Dutch shoemakers continued to make and sell shoes in St. Martin's Lane. The liberties of St. Martin's, having been sacralized during the fifteenth century as they were folded into the church's immunities, were desacralized and disaggregated again in the sixteenth. 


\section{Notes}

I would like to thank, for various kinds of help on this article, Kit French, John A. W. Lock, Margaret McGlynn, Eric Reiter, and Christine Reynolds of the Westminster Abbey Library. Derek Parent made the map. I am also grateful for the valuable suggestions made by Nicole Rice, Margaret Pappano, and the two anonymous reviewers for JMEMS.

${ }^{1}$ Kew, The National Archive (hereafter TNA), C 24/3, "Abbas ad probandum metas et bundas sanctuarii sancti Martini," mm. 6-7, 9-11; STAC 2/20/323, mm. 19-23, 24-28.

${ }^{2}$ Alfred John Kempe, Historical Notices of the Collegiate Church or Royal Free Chapel and Sanctuary of St. Martin-le-Grand, London (London, 1825); William Page, ed., "Colleges: St. Martin le Grand," in The Victoria History of the County of London (London: Constable, 1909), 555-66; Shannon McSheffrey, "Sanctuary and the Legal Topography of Pre-Reformation London," Law and History Review 27, no. 3 (2009): 483-514.

${ }^{3}$ McSheffrey, "Sanctuary."

${ }^{4}$ TNA, STAC 2/20/323, m. 26.

${ }^{5}$ Ibid., m. 27.

${ }^{6}$ TNA, C 24/3, “Abbas,” mm. 9-10; STAC 2/20/323, mm. 20-21.

${ }^{7}$ TNA, STAC 2/20/323, mm. 21-22.

${ }^{8}$ London Metropolitan Archives (hereafter LMA), Journ. 13, fols. 186v, 194r 96v, 410v-14r, 420v, 453r, 467r - 68v; Rep. 9, fols. 26v, 46r, 48r, 51r, 59v, 61v, 62r, 63r - v, 85v, 104r, 109v - 10r, 135r; Rep. 10, fols. 9r - v, 10r, 31v, 36r, 62r, 88v; TNA, C 24/3, "Abbas" (copy in STAC 2/23/266; abbreviated in STAC 2/20/57); STAC 2/20/323; STAC 2/20/324.

${ }^{9}$ TNA, STAC 2/20/324, m. 5; STAC 2/29/198.

${ }^{10}$ See the areas marked as "ex-par." on the maps "Wards c. 1520" and "Parishes c. 1520," in Mary S. Lobel, The City of London From Prehistoric Times to c. 1520 (Oxford: Oxford University Press, 1989), 120-23.

${ }^{11}$ See, e.g., Frank Rexroth, Deviance and Power in Late Medieval London, trans. Pamela Eve Selwyn (Cambridge: Cambridge University Press, 2007), 20. On liberties, see Caroline Barron's London in the Later Middle Ages: Government and People, 1200-1500 (Oxford: Oxford University Press, 2004), 34-37; Martha Carlin, Medieval Southwark (London: Hambledon Press, 1996), 101-28 and 20930; Anthony Paul House, "The City of London and the Problem of the Liberties, c. 1540-c. 1640" (Ph.D. diss., Oxford University, 2006); Ingrid R. Wilkerson, "Strangers in Good Company: Immigrants in Elizabethan London" (Ph.D. diss., University of California, Irvine, 2009).

${ }^{12}$ On sanctuary and English law, see R. H. Helmholz, The "ius commune" in England: Four Studies (Oxford: Oxford University Press, 2001), 16-81; J. H. Baker, The Oxford History of the Laws of England, Volume 6: 1485-1558 (Oxford: Oxford University Press, 2003), 540-51; Karl Shoemaker, Sanctuary and Crime in the Middle Ages, 400-1500 (New York: Fordham University Press, 2011). On 
St. Martin le Grand, see Kempe, Historical Notices; Page, "Colleges: St. Martin le Grand"; Isobel Thornley, "The Destruction of Sanctuary," in Tudor Studies, ed. R. W. Seton-Watson (London: Longmans, Green, and Co., 1924), 182-207; Isobel Thornley, "Sanctuary in Medieval London," Journal of the British Archaeological Association 38 (1932): 293-315; Marjorie B. Honeybourne, "The Sanctuary Boundaries and Environs of Westminster Abbey and the College of St. Martin-leGrand," Journal of the British Archaeological Association 38 (1932): 316-34; Barron, London, 1200-1500, 36-37; McSheffrey, "Sanctuary."

${ }^{13}$ See J. L. Bolton, ed., The Alien Communities of London in the Fifteenth Century (Stamford, Lincolnshire: Richard III and Yorkist History Trust, 1998), 28-30; Andrew Pettegree, Foreign Protestant Communities in Sixteenth-Century London (Oxford: Clarendon Press, 1986); Derek Keene, "Du seuil de la Cité à la formation d'une économie morale: L'environnement hanséatique à Londres, entre XIIe et XVIIe siècle," in Les étrangers dans la ville: Minorités et espace urbain du bas moyen âge à l'époque moderne, ed. Jacques Bottin and Donatella Calabi (Paris: Editions de la Maison des sciences de l'homme, 1999), 409-24, at 410.

${ }^{14}$ The liberties have been curiously neglected in some of the major scholarship on aliens in later medieval London, omitted, for instance, from Sylvia L. Thrupp, "Aliens in and around London in the Fifteenth Century," in Studies in London History Presented to Philip Edmund Jones, ed. Albert E. J. Hollaender and William Kellaway (London: Hodder and Stoughton, 1969), 251-72; and Bolton, Alien Communities, 11-15. Both Archer and Barron comment usefully, if briefly, on the question. Ian W. Archer, "Responses to Alien Immigrants," in Le migrazioni in Europa, secc. xiii-xviii, ed. Simonetta Cavaciocchi (Firenze: Le Monnier, 1994), 755-74; Barron, London, 1200-1500, 35-36.

${ }^{15}$ A list of jurors in the precinct in 1440 includes several with Dutch-sounding names (Westminster Abbey Muniments [hereafter WAM], MS 13191, fol. 1r), and provisions were made for aliens in St. Martin's in statutes of the 1460s and 1470s: 3 Edw. IV, c. 4, 5, and 17 Edw. IV, c. 1, in The Statutes of the Realm (12251713), 9 vols. in 10 (London, 1810-22), 2:396-402, 452-61.

${ }^{16}$ Archer, "Responses."

${ }^{17}$ For a spreadsheet of this data, see Shannon McSheffrey, "Residents of St. Martin-le-Grand, c. 1500-1550," at http://shannonmcsheffrey.wordpress.com/research/ (accessed Mar. 8, 2013).

${ }^{18}$ R. G. Lang, ed., Two Tudor Subsidy Rolls for the City of London, 1541 and 1582 (London: London Record Society, 1993), at British History Online, http://www.british-history.ac.uk/source.aspx?pubid=160. The 1541 subsidy both specifies who lived within the precinct boundaries (as opposed to generally within the parishes and ward in which the precinct fell, as most of the other assessment rolls do), and distinguishes stranger and English. This is higher than Andrew Pettegree's estimate for aliens in St. Martin's (56 percent), in "The Foreign Population of London in 1549," Proceedings of the Huguenot Society of London 24, no. 2 (1984): 141-46, at 144. See McSheffrey, "Residents of St. Martin-le-Grand," for a discussion. 
${ }^{19}$ Pettegree, Foreign Protestant Communities, 15-16; Lien Bich Luu, Immigrants and the Industries of London, 1500-1700 (Aldershot, Hampshire: Ashgate, 2005), 143-44. See below for one anomalous individual, Peter Peterson, listed among the "English" but termed a denizen and assessed at the alien rate. As he was born abroad, he is here counted as a stranger.

${ }^{20}$ While all adult alien males were assessed, only English heads of households with land or goods worth more than twenty pounds were assessed in 1541. Lang (Tudor Subsidy Rolls, $\mathrm{xx}, \mathrm{xl}$ ) estimates that 25 percent of household heads were assessed in London and that average household size was 4.5 (or 2.25 males per household). Here the raw count for the English is multiplied by 9 ( $4 \mathrm{x}$ 2.25); this may be an overestimate, as not all males would have been over the age of fourteen. The adjusted count would therefore be 207 strangers and 45 English.

${ }^{21}$ Lang, Tudor Subsidy Rolls, 7-9.

${ }^{22}$ TNA, PCC Prob. 11/28, fol. 35v, Will of Gabriel Tijsman (1541).

${ }^{23}$ Lang, Tudor Subsidy Rolls, 7; TNA, PCC Prob. 11/28, fol. 35v.

${ }^{24}$ See TNA, PCC Prob. 11/43, fol. 402r, Will of Gertrude Myles (1560); C 1/987/32; PCC Prob. 11/70, fol. 130r-v, Will of Peter Richardson (1583); William Page, Letters of Denization and Acts of Naturalization for Aliens in England, 1509-1603 (Nendeln, Liechtenstein: Kraus Reprint, 1969), 47, 48, 53, 55, 57, 58, 98-99, 124, 135, 191, 194, 206, 221, 248, 256; Letters and Papers, Foreign and Domestic, of the Reign of Henry VIII, ed. J. S. Brewer, James Gairdner, and R. H. Brodie, 22 vols. in 35 (London: Public Record Office, 1862-1932), 11:209.

${ }^{25}$ Page, Letters of Denization, 16, 68, 76, 77, 78, 96, 123, 184.

${ }^{26}$ Bolton, Alien Communities, 33-34; Luu, Immigrants, 100-112.

${ }^{27}$ See Luu's distinction between individual migration and mass migration and occupational choice. Mass migrations of religious refugees from the Netherlands to London began only in the 1560s (Immigrants, 3-4, 13-17).

${ }^{28}$ See, e.g., Lang, Tudor Subsidy Rolls, 7-9.

${ }^{29}$ Some of the depositions have signatures; most have artisans' marks. TNA, C 24/3, "Abbas," passim. On artisans' marks, see Charles Sisson, "Marks as Signatures," The Library Ser. 4, vol. 9, no. 1 (1928): 1-35; Marie Claude Guigue, De l'origine de la signature et de son emploi au moyen âge (Paris, 1863).

${ }^{30}$ On complaints, see, e.g., Chris Given-Wilson, ed., The Parliament Rolls of Medieval England, 1275-1504, 16 vols. (Woodbridge, Suffolk: Boydell Press, 2005), 2:396, and at British History Online, http://www.britishhistory.ac.uk/report.aspx?compid=116552; LMA, Journ. 10, fols. 209v-10r; Barron, London, 1200-1500, 35-36. On cachet, see Luu, Immigrants, 59-61.

${ }^{31} 4$ Edw. IV, c. 7, Statutes of the Realm, 2:414-15; Isabella Whitney, "The maner of her Wyll, \& what she left to London," in A sweet nosgay, or pleasant posye, STC (2nd ed.) 25440 (London, 1573), sig. E4v.

${ }^{32}$ Lien Bich Luu, "Aliens and Their Impact on the Goldsmiths' Craft in London in the Sixteenth Century," in Goldsmiths, Silversmiths, and Bankers: Innovation and 
the Transfer of Skill, 1550 to 1750, ed. David Mitchell (Stroud, Gloucestershire: Alan Sutton, 1995), 43-52.

${ }^{33}$ See WAM, MSS 13191 and 13294; TNA, C 24/3, “Abbas," m. 17.

${ }^{34}$ WAM, MS 13313. Payne may have been rent-gatherer as early as 1514 (see WAM, MS 13315).

${ }^{35}$ For other sanctuary registers, see Sanctuarium Dunelmense et Sanctuarium Beverlacense, ed. James Raine, Surtees Society, vol. 5 (London, 1837).

${ }^{36}$ TNA, KB 15/42, fols. 140v-41r; STAC 2/21/121; C 1/964/24; SP 1/237, fol. 282r; LMA, COL/CA/01/01/001, Repertory of the Court of Aldermen, vol. 1, fol $97 \mathrm{v}$.

${ }^{37}$ TNA, E 101/674/4. See also Letters and Papers, 18/2:118.

${ }^{38}$ WAM, WARB, vol. 2, fols., 23rv, 109v-10r, 188v-89r, 234r; TNA, PCC Prob. 11/29, fols. 173r-74r, Will of Hugh Payne; Kempe, Historical Notices, 205-10.

${ }^{39}$ WAM, WARB, vol. 2, fol. $165 \mathrm{r}-\mathrm{v}$; vol. 3, fols. 84v-85r, 85r-86r, 87v-88r, 90r91r; TNA, KB 27/1023, plea m. 61 (Payne and other defendants to a suit of trespass had a Common Pleas suit brought to King's Bench on a writ of error); TNA, C 24/3, “Abbas," passim; TNA, PCC Prob. 11/29, fols. 173r-74r, Will of Hugh Payne.

${ }^{40}$ TNA, C $1 / 636 / 18$.

${ }^{41}$ TNA, STAC 2/21/121.

${ }^{42}$ Kevin Sharpe, Selling the Tudor Monarchy: Authority and Image in SixteenthCentury England (New Haven, Conn.: Yale University Press, 2009), 55, 67-68, 84-85, 121; Paul L. Hughes and James Francis Larkin, eds., Tudor Royal Proclamations, 3 vols. (New Haven, Conn.: Yale University Press, 1964-69), 1:227-28, 272; Irvin Buckwalter Horst, The Radical Brethren: Anabaptism and the English Reformation to 1558 (Nieuwkoop, Neth.: De Graaf, 1972), 60-62.

${ }^{43} 32$ Hen. VIII, c. 16, Statutes of the Realm, 3:765-66.

${ }^{44}$ TNA, SP 1/162, fols. 69r, 71r-v; Letters and Papers, 15:495-96.

${ }^{45}$ Page, Letters of Denization, 16, 47, 48, 53, 55, 57, 58, 68, 98-99, 206, 248; Pettegree, Foreign Protestant Communities, 15.

${ }^{46}$ On the statutes more generally, see Steve Rappaport, Worlds within Worlds: Structures of Life in Sixteenth-Century London (Cambridge: Cambridge University Press, 1989), 45-47. For exemptions for St. Martin's, see, e.g., 3 Edw. IV, c. 4, 5; 17 Edw. IV, c. 1; 14 and 15 Hen. VIII, c. 2; 21 Hen. VIII, c. 16; Statutes of the Realm, 2:396-402, 452-61; 3:208-9, 297-98. The only statute governing alien labor in this period which does not exempt St. Martin's is 1 Ric. III, c. 9, Statutes of the Realm, 2:489-93.

${ }^{47}$ Statutes of the Realm, 3:297-301. The letter patent establishing the commission, dated Feb. 14, 1529 and ratified in 21 Hen. VIII, c. 16, was also copied into the Journal of the Court of Common Council (LMA, Journ. 13, fol. $194 \mathrm{r}-\mathrm{v})$. Perhaps significantly, this copy makes no mention of the provisions exempting artisans in St. Martin le Grand.

${ }^{48}$ LMA, Journ. 13, fols. 195r-96v; WAM, MSS 13195A-13195H. 
${ }^{49}$ TNA, STAC 3/7/68. See similarly, TNA, C 1/913/66. This recalled the Evil May Day riots that targeted St. Martin's, on which I intend to write a separate study.

${ }^{50}$ See the depositions in TNA, C 24/3, "Abbas," passim.

${ }^{51}$ LMA, Journ. 13, fol. 410v.

${ }^{52}$ LMA, Rep. 9, fols. 46r, 48r, 51r, 63r; Journ. 13, fols. 410v-14r, 420v-21r.

${ }^{53}$ LMA, Journ. 13, fol. 453r; TNA, C 24/3, "Abbas" (copy in STAC 2/23/266; abbreviated in STAC 2/20/57); STAC 2/20/323; STAC 2/20/324 (cf. Journ. 13, fols. 195r-96v).

${ }^{54}$ See LMA, Journ. 13, fols. 186v, 194-96v, 410v-14r, 420v, 453r, 467r-68v; Rep. 9, fols. 26v, 46r, 48r, 51r, 59v, 61v, 62r, 63rv, 85v, 104r, 109v-10r, 135r; Rep. 10, fols. 9rv, 10r, 31v, 36r, 62r, 88v; TNA, STAC 2/20/324; STAC 2/20/323; C 24/3, "Abbas."

${ }^{55}$ TNA, STAC $2 / 20 / 324$, m. 2.

${ }^{56}$ TNA, STAC $2 / 20 / 324$, mm. 5-8.

${ }^{57}$ Copy entered into LMA, Journ. 13, fol. 453r.

${ }^{58}$ I erred on this question in McSheffrey, "Sanctuary," 506.

${ }^{59} 32$ Hen. VIII, c. 16, Statutes of the Realm, 3:756-58.

${ }^{60}$ Lang, Two Tudor Subsidy Rolls, 7-9; TNA, E 179/144/123 (1543), m. 5; E 179/145/137 (1545 subsidy), m. 1; PCC Prob. 11/29, fols. 173r-74r, Will of Hugh Payne.

${ }^{61}$ TNA, REQ 2/4/333.

${ }^{62}$ On Pott, see TNA, C 24/3, "Abbas," m. 6; STAC 2/23/266, mm. 20-22; STAC $2 / 20 / 323, \mathrm{~mm} .4-6$. Wesell is probably the same as the alien shoemaker Henry Wees or Wayes. See E 179/144/109 (1534 subsidy); E 179/144/123 (1543 subsidy); E 179/145/137, rot. 1 (1545 subsidy); Lang, Tudor Subsidy Rolls, 7-9. TNA, PCC Prob. 11/31, fol. 9v, Will of Garret Sluter.

${ }^{63}$ Page, Letters of Denization, 191; TNA, C 24/3, “Abbas,” m. 1; TNA, PCC Prob. 11/32, fols. 123v-24r, Will of Peter Peterson (1548); Luu, Immigrants, 144-46.

${ }^{64}$ LMA, Rep. 10, fol. 88v; Rep. 11, fols. 28r, 30r, 32v, 34v; TNA, PCC Prob. 11/32, fol. 123v, Will of Peter Peterson (1538); TNA, PCC Prob. 11/37, fol. 40v, Will of Agnes Peterson (1555). The cordwainers' company records do not survive for this period.

${ }^{65}$ LMA, Rep. 9, fol. 62r; Journ. 13, fols. 410v, 420v.

${ }^{66}$ Lang, Tudor Subsidy Rolls, 7.

${ }^{67}$ TNA, E 179/144/109 (1534 subsidy); Lang, Tudor Subsidy Rolls, 7-9.

${ }^{68}$ Nor, in fact, did any of the City's witnesses follow the City's viewpoint, as all testified that St. Martin's was a sanctuary and that its privileges extended to stranger artisans; they differed from the St. Martin's witnesses in where they drew the precinct boundaries. See TNA, STAC 2/20/323.

${ }^{69}$ TNA, C 24/3, "Abbas," mm. 1-2.

70 TNA, PCC Prob. 11/29, fols. 173r-74r, Will of Hugh Payne; Lang, Tudor Subsidy Rolls, 7-9.

${ }^{71}$ See their wills in TNA, C 24/3, "Abbas," mm. 1-2. 
${ }^{72}$ TNA, KB 9/452, m. 61; KB 9/473, m. 73; KB 9/473, m. 75; KB 9/473, m. 76; KB 9/474, m. 61; KB 9/539, m. 39.

${ }^{73}$ TNA, KB 9/473, m. 75; KB 9/539, m. 39.

${ }^{74}$ TNA, SP 1/33, fol. 148r; Letters and Papers, 4/1:473.

${ }^{75}$ For instance, between 1500 and 1540 I have found references to twenty-six people who sought sanctuary at St. Martin's, sometimes only briefly. See McSheffrey, "Residents of St. Martin-le-Grand" for details, searching "sanctuary."

${ }^{76}$ See TNA, SP 1/238, fol. 72r. Conversely, leases recorded in the Westminster Abbey sanctuary do not show aliens leasing property there as they do for St. Martin's. WAM, WARB, vols. 2 and 3, passim.

${ }^{77}$ TNA, STAC 2/20/323, m. 21; C 24/3, “Abbas," m. 15.

${ }^{78}$ TNA, C $1 / 636 / 18$.

${ }^{79}$ TNA, C 1/888/11, C 1/946/26, C 1/965/24-25; “1538-40 Rental," in Kempe, Historical Notices, 207.

${ }^{80}$ For more on the precinct's topographical aspects, see McSheffrey, "Sanctuary."

${ }^{81}$ TNA, C 24/3, "Abbas," m. 4; STAC 2/23/266, mm. 13-16; Letters and Papers, 3/1:553.

${ }^{82}$ TNA, PCC Prob. 11/46, fol. 281r-v, Will of Garret Williamson, 1563; WAM, WARB, vol. 2, fol. 226r. Williamson was taxed on $£ 60$ in goods in 1534 and 1541, and $£ 40$ in goods in 1543 and 1545. TNA, E 179/144/109 (1534 subsidy); E 179/144/123 (1543), rot. 5; E 179/145/137 (1545 subsidy), rot. 1; Lang, Two Tudor Subsidy rolls, 7.

${ }^{83}$ Agnes Peterson names Peter Peterson, alias Johnson, as her late husband's nephew. TNA, PCC Prob. 11/37, fol. 40v, Will of Agnes Peterson (1555).

${ }^{84} 32$ Hen. VIII, c. 16, Statutes of the Realm, 3:756-58. The act did not abolish sanctuary but attempted to instate a secular sanctuary system, which in the end did not apparently become truly functional. The workings of sanctuary privilege in the decades that follow 1540 has not, however, been fully investigated.

${ }^{85}$ Letters and Papers, 17:34, 393, 396.

${ }^{86}$ Kempe, Historical Notices; House, “City of London,” 30-31, 183-220. 